\title{
TYROSINE KINASE EXPRESSION ANALYSES IN CANINE MAMMARY GLAND TUMOURS - A PILOT STUDY
}

\author{
Zsófia KOLTAI $^{1 *}$, Bernadett SzABÓ ${ }^{1}$, Judit JAKUS ${ }^{2}$ and Péter VAJDOVICH ${ }^{1,2}$ \\ ${ }^{1}$ Veterinary Haematology and Oncology Centre, Bolgárkertész u. 31, H-1148 Budapest, \\ Hungary; ${ }^{2}$ Department of Clinical Pathology and Oncology, University of Veterinary \\ Medicine, Budapest, Hungary
}

(Received 15 August 2017; accepted 16 April 2018)

\begin{abstract}
Messenger RNA levels of oncogenic tyrosine kinases were determined in canine mammary tumours using real-time RT-PCR. The following tyrosine kinases and vascular endothelial growth factors (VEGF) were examined in malignant and healthy mammary tissues of 13 dogs: VEGFR1, VEGFR2, EGFR, ErbB2, PDGFR1, c-KIT and c-MET. Expression levels of all these factors were significantly higher in tumour samples than in normal mammary tissues taken from the same animal. Higher grading was associated with higher VEGFR1 levels. Grade III tumours showed significantly higher VEGF, c-MET and c-KIT mRNA expression, while Grade I tumours with lower malignancy showed significantly higher PDGFR1 and EGFR expression than tumours classified as Grade II or III. The increased presence of VEGF, VEGFR1, c-KIT and c-MET is a negative prognostic factor as these signal transduction molecules contribute to increased tumour malignancy. The presented data provide evidence, for the first time, for the existence of a complex overexpression and dysregulation of VEGF and several oncogenic tyrosine kinases such as VEGR1, PDGFR1, c-KIT and c-MET in canine mammary tumours. Therefore, canine mammary tumours may be potential targets for tyrosine kinase inhibitor therapy.
\end{abstract}

Key words: Canine mammary tumour, chemotherapy, receptor tyrosine kinases, real-time RT-PCR

Mammary gland tumours (MGT) are the most common neoplastic diseases in dogs. According to a relatively wide-scale study, the incidence rate is 191.8 with a relative frequency of $70.5 \%$ in females and $2.2 \%$ in males (Merlo et al., 2008). The primary treatment of the disease is surgical excision, but the tumours tend to recur, so often there is a need for additional treatment options, such as chemotherapy. The majority of breast cancers show varying degrees of resistance

*Corresponding author; E-mail: zskoltai@gmail.com; Phone: 0036 (1) 788-0734; Fax: 0036 (1) 788-0734

Open Access. This is an open-access article distributed under the terms of the Creative Commons AttributionNonCommercial 4.0 International License (https://creativecommons.org/licenses/by-nc/4.0/), which permits unrestricted use, distribution, and reproduction in any medium for non-commercial purposes, provided the original author and source are credited, a link to the CC License is provided, and changes - if any - are indicated. 
to classic chemotherapeutic agents administered iv., as tumours arising from tissues with physiologically high multidrug resistance have a so-called 'intrinsic resistance' against chemotherapeutic drugs. Mammary gland tumours belong to this type of cancers, and therefore the use of chemotherapy is often not sufficient (Bergman, 2000).

Some examples of important prognostic markers that have been evaluated in canine mammary tumours are hormone receptors (oestrogen receptor - ER, and progesterone receptor $-\mathrm{PR}$ ), a marker of the tumour proliferative index (MIB-1), a marker of angiogenesis (CD31), adhesion molecules (E-cadherin and $\beta$-catenin), epidermal growth factor (EGF), p53 and the human epidermal growth factor receptor 2 (HER-2) oncogene (Cassali et al., 2011). The dysregulation of receptor tyrosine kinases (RTK), and so the abnormal activation of signalling pathways, is a well-known phenomenon in several human tumours. The most important RTKs include KIT proto-oncogene receptor tyrosine kinase (c-KIT), MET proto-oncogene (c-MET), epidermal growth factor receptor (EGFR), and anaplastic lymphoma kinase (ALK). They can be activated, among others, by mutation, overexpression or chromosomal translocation (London, 2013). Three or more activated RTKs, including EGFR, ErbB3, PDGFR (platelet-derived growth factor receptor alpha) and c-MET, can be detected in several tumour cells (Stommel et al., 2007). RTK coactivation is not a distinctive feature of one tumour type, as similar patterns were detected in gliomas and other solid tumours such as lung and breast carcinoma as well as pancreatic adenocarcinoma cell lines, among others (Xu and Huang, 2010).

RTK signalling pathways play a crucial role in various cellular functions and in the regulation of angiogenesis, as well as in the primary process of the continuous growth of tumour cells (Lemmon and Schlessinger, 2010; Clemente et al., 2013). The receptor tyrosine kinases can induce angiogenesis via the following proteins: vascular endothelial growth factor receptor (VEGFR), plateletderived growth factor receptors (PDGFR), fibroblast growth factor receptor (FGFR), tyrosine kinase with immunoglobulin-like and EGF-like domains 1 (TIE-1), and TEK receptor tyrosine kinase (TEK or TIE-2). VEGFR is expressed in the vascular endothelium and its signalling pathway results in endothelial migration and proliferation. PDGFR is expressed in stroma and vascular pericytes, and has a critical role in maintaining the newly formed blood vessels. Moreover, it promotes angiogenesis via VEGF transcription and secretions of excitation. FGFR is expressed in the vascular endothelial cells and, together with the VEGFR, promotes the increased expression of VEGFTIE-1 and TEK, which are formed in the tumour blood vessels and have an important role in the migration of pericytes and smooth muscle cells, and thereby in the formation of new blood vessels (Cherrington et al., 2008).

Tyrosine kinase mutations, especially the c-KIT mutation, are particularly important, since they act as the targets of some small-molecule tyrosine kinase inhibitors (toceranib, masitinib) in veterinary use. The c-KIT mutation causes in- 
creased proliferation and/or reduced tendency of apoptosis, and can be found in a significant part of Grade II and Grade III mast cell tumours in dogs (Patruno et al., 2014).

The c-KIT gene encodes the c-KIT protein (also known as CD117 or SCFR) of the stem cell factor (SCF) receptor. During mutation, internal tandem duplication occurs in the juxtamembrane domain of the c-KIT tyrosine kinase, and causes autophosphorylation even in the absence of the ligand (Downing et al., 2002). c-KIT is normally found in haematopoietic cell lines (it has a decisive role as haematopoietic progenitor), melanocytes, cells of the central nervous system, and mastocytes, helping the migration, proliferation, survival and the expression of histamine tryptase (Galli et al., 1994). Its mutation can also be found in approximately $50 \%$ of human gastrointestinal stromal tumours (GIST) and was also described in GIST of dogs (Frost et al., 2003). In human breast and ovarian carcinomas, the increased expression of the HER2 receptor tyrosine kinase, also known as ErbB2, often correlates with a more aggressive phenotype (London, 2013).

The c-MET gene is responsible for the production of the oncogene c-MET receptor tyrosine kinase (HGFR) located on the surface of the epithelium, which so far has only one known ligand, the hepatocyte growth factor (HGF). HGF is the best known physiological inducer of invasive or diffusion-accompanied cell proliferation, therefore it plays a significant role in tumour metastasis. c-MET also plays an important role during embryonic development and wound healing. In addition, its activation inhibits apoptosis and induces the proliferation of other RTKs. Under physiological conditions, it is expressed by stem and progenitor cells, but its expression has also been reported in many human tumours (Stellrecht and Gandhi, 2009). It is important to note that the HGF/c-MET is closely related to the EGFR signalling pathway, and the binding of HGF can induce signalling via the EGFR, or in tumour cells with a permanent presence of EGF. MET phosphorylation may occur in the absence of HGF as well (Stellrecht and Gandhi, 2009).

The aim of this study was to describe the expression profile of a selected group of tyrosine kinases which may play an important role in the development of canine mammary tumours, and to elucidate if this type of tumours could be a good candidate for treatment with tyrosine kinase inhibitors.

\section{Materials and methods}

\section{Ethics statement}

All procedures in this study were conducted according to the guidelines of the Local Ethics Committee of Animal Welfare of the University of Veterinary Medicine, Budapest, Hungary. 


\section{Animals and sampling}

Thirteen female dogs with mammary cancer (average age: 9.8 years) were included in the study. The histological classification and grading of the tumours are shown in Table 1. In each case, one healthy mammary gland with no tumour lesion (later serving as control) was also removed.

Table 1

Canine patients with mammary gland cancer

\begin{tabular}{lccc}
\hline Breed & Age/gender & $\begin{array}{c}\text { Histological classification } \\
\text { of the tumour }\end{array}$ & Grading \\
\hline Hovawart & $10 \mathrm{y} /$ female & complex carcinoma & grade I \\
Dachshund & $12 \mathrm{y} /$ female & complex carcinoma & grade I \\
Mixed breed & $6 \mathrm{y} . /$ female & complex carcinoma & grade I \\
Miniature Poodle & $7.5 \mathrm{y} . /$ female & complex carcinoma & grade I \\
Mixed breed & $11 \mathrm{y} . /$ female & osteoblastic osteosarcoma & grade I \\
Labrador Retriever & $8 \mathrm{y} . /$ female & chondrosarcoma & grade II \\
Rottweiler & $8 \mathrm{y} /$ female & spindle cell carcinoma & grade II \\
Beagle & $11 \mathrm{y} /$ female & simple carcinoma & grade II \\
Chihuahua & $17 \mathrm{y} /$ female & complex carcinoma & grade II \\
Boxer & $11 \mathrm{y} /$ female & simple carcinoma & grade II \\
Dachshund & n.a./female & simple carcinoma & grade III \\
German Shepherd & $11 \mathrm{y} . /$ female & simple carcinoma & grade III \\
Dachshund & $12 \mathrm{y} /$ female & simple carcinoma & grade III \\
\hline
\end{tabular}

The MGT tissues were further analysed if there was no visible necrosis. A small piece weighing 0.5-1.0 gram was removed from the samples and homogenised with a Potter-Elvehjem-type homogeniser using $1 \mathrm{ml}$ of Trizol reagent (Total RNA Isolation Reagent, Invitrogen). Samples were stored at $-80^{\circ} \mathrm{C}$ for further processing.

\section{RNA extraction and DNase digestion}

The samples were incubated at $4{ }^{\circ} \mathrm{C}$ for $5 \mathrm{~min}$, then vortexed for $15 \mathrm{~s}$ after the addition of $0.2 \mathrm{ml}$ of $-20^{\circ} \mathrm{C}$ chloroform. This was followed by additional 5 min of incubation at $4{ }^{\circ} \mathrm{C}$ and by a 15 -min centrifugation at $12,000 \mathrm{~g}$ at $4{ }^{\circ} \mathrm{C}$. After centrifugation, the RNA was cautiously removed from the upper aqueous phase and pipetted into a sterile Eppendorf tube. This process was repeated once more for further purification of the solution. To precipitate the RNA, cooled isopropyl alcohol was mixed into the above extracted solution in 1:1 ratio (Merck 100995.1000), then vortexed again, and incubated at $4{ }^{\circ} \mathrm{C}$ for 5 min. This was 
followed by centrifugation with $12,000 \mathrm{~g}$ at $4{ }^{\circ} \mathrm{C}$ for $10 \mathrm{~min}$. Finally, the supernatant was decanted, and the RNA further purified. During this process, $1 \mathrm{ml}$ of ice-cold 75\% ethanol (Merck 100971.1000) was added, vortexed again and the sample was centrifuged with $7,500 \mathrm{~g}$ at $4{ }^{\circ} \mathrm{C}$ for $5 \mathrm{~min}$. The last two steps were repeated. During the re-solubilisation of the RNA, the liquid phase was pipetted, then the pellet was air-dried for additional 5-10 min. After drying, it was dissolved in $50 \mu \mathrm{l}$ of RNase-free water (Merck). The sample was stored at $-80^{\circ} \mathrm{C}$ for further investigation.

\section{cDNA writing}

The cDNA writing (Reverte ${ }^{\mathrm{TM}} \mathrm{H}$ Minus First Strand cDNA Synthesis Kit, Fermentas) for all the samples was performed as follows: to $1 \mu \mathrm{g}$ RNA sample $1 \mu 1$ random hexamer primer was added, then DEPC-treated water was measured to get a final volume of $12 \mu$. These were thoroughly mixed, centrifuged and incubated at $70{ }^{\circ} \mathrm{C}$ for $5 \mathrm{~min}$ followed by cooling to $4{ }^{\circ} \mathrm{C}$. Droplets stuck to the pipe's wall were collected by an additional centrifugation. To the mixture (continuously working on ice) $4 \mu \mathrm{l}$ five times concentration of reaction buffer, $20 \mathrm{U} / \mu \mathrm{l}$ ribonuclease inhibitor and $2 \mu \mathrm{l}$ of $10 \mathrm{mM}$ dNTP mix were added. The solution was mixed and centrifuged. After 5-min incubation at $25{ }^{\circ} \mathrm{C}$, we added the reverse transcriptase enzyme $(200 \mathrm{U} / \mu \mathrm{l})$ to get a final volume of $20 \mu \mathrm{l}$. This was followed by incubation for $10 \mathrm{~min}$ at $25{ }^{\circ} \mathrm{C}$ and $60 \mathrm{~min}$ at $42{ }^{\circ} \mathrm{C}$ afterwards, then in order to inactivate the enzyme the solution was maintained at $72{ }^{\circ} \mathrm{C}$ for $10 \mathrm{~min}$. The prepared cDNA was stored at $-20^{\circ} \mathrm{C}$ for further processing.

\section{Real-time PCR}

A Mini Opticon ${ }^{\mathrm{TM}}$ (Biorad) PCR instrument was used for real-time PCR. Primers were designed with the Primer-BLAST program provided by SigmaAldrich and Bioscience (Table 2). In each sample, mRNAs were examined in two replicates. In the reaction $25 \mu$ IQ SYBR Green Supermix (Biorad), $18 \mu 1$ DEPC water, and $1 \mu \mathrm{l}$ primer pair each were used for $5 \mu \mathrm{l}$ cDNA.

The PCR reaction was started with 3 min of enzyme activation at $95{ }^{\circ} \mathrm{C}$ followed by 40 additional cycles as follows: $10 \mathrm{~s}$ at $95{ }^{\circ} \mathrm{C}, 10 \mathrm{~s}$ at $56^{\circ} \mathrm{C}$ and $20 \mathrm{~s}$ at $72{ }^{\circ} \mathrm{C}$. The products of the reaction were monitored/controlled with the melting curve and by running an agarose gel. HPRT was used as a housekeeping protein. Data analysis was carried out using the optical system software of the PCR (BioRad), which calculates the threshold cycle numbers $(\mathrm{Ct})$.

\section{Statistical analysis}

Student's $t$-test and Kruskal-Wallis ANOVA were applied to analyse the variation in the expression of different canine mRNAs compared to control val- 
ues. Then the data were divided into ordinal categories of grade, and MannWhitney tests were used for pairwise comparisons. The value of $\mathrm{P}<0.05$ was considered significant. All analyses were performed using the Statistica software (StatSoft Inc., USA).

Table 2

PCR primers used

\begin{tabular}{|c|c|}
\hline canis EGFR & $\begin{array}{l}\text { forward 5'-CGCAGACTGCTGCAAGAAAG-3' } \\
\text { reverse 5'-CAAGAGAGCCTGGTTGGGAG-3' }\end{array}$ \\
\hline canis ERbB2 & $\begin{array}{l}\text { forward 5'-GACCCACCTGGATATGCTCC-3' } \\
\text { reverse 5'-TTGGCAGGCAGGTAAGTGAG-3' }\end{array}$ \\
\hline canis VEGFR1 & $\begin{array}{l}\text { forward 5'-ATTCGAGGAAAGGGGAAGGG-3' } \\
\text { reverse 5'-AGGGAACGCTCCAGGGTTTA-3' }\end{array}$ \\
\hline canis VEGFR2 & $\begin{array}{l}\text { forward 5'-GTTGGGAGAGGAGAGAGGGT-3' } \\
\text { reverse 5'-CAGTGCACCACAAAGACACG-3' }\end{array}$ \\
\hline canis VEGF & $\begin{array}{l}\text { forward 5'-TGGTCCCAGGCTGCGCCTAT-3' } \\
\text { reverse 5'-GACGGCAGTAGCTGCGCTGG-3' }\end{array}$ \\
\hline canis PDGFR1 & $\begin{array}{l}\text { forward 5'-GAGGAACAGACACAGCTCACA-3' } \\
\text { reverse 5'-TCCTCGATGGTTTCGTCCTC-3' }\end{array}$ \\
\hline canis KIT & $\begin{array}{l}\text { forward 5'-GGAAGCCTCTTCCCAAGGAC-3' } \\
\text { reverse 5'-TACTCGCGCTTCACGTTTCT-3' }\end{array}$ \\
\hline canis MET & $\begin{array}{l}\text { forward 5'-TCTCTCTTTGAACATGTTTTGGCA-3' } \\
\text { reverse 5'-AGAAGCACAAGGATGCCAGG-3' }\end{array}$ \\
\hline HPRT & $\begin{array}{l}\text { forward 5'-GACCAGTCAACAGGGACAT-3' } \\
\text { reverse 5'-ACACTTCGAGGGGTCCTTTT-3' }\end{array}$ \\
\hline
\end{tabular}

\section{Results}

The results of the real-time RT-PCR analyses are expressed as relative gene expression compared to the housekeeping HPRT gene used as a reference.

Changes in mRNA levels of tyrosine kinases in dogs with mammary cancer

mRNA expression of tyrosine kinases was measured in tumour $(n=13)$ and normal $(\mathrm{n}=13)$ mammary gland colony samples, respectively, taken from the same animal. The assays confirmed that the measured mRNA levels of all studied proteins, VEGFR1 (Fig. 1A), VEGFR2 (Fig. 1B), PDGFR1/PDGFR $\alpha$ (Fig. 1C), EGFR (Fig. 1D), ErbB2 (Fig. 1E), c-KIT (Fig. 1F), c-MET (Fig. 1G), and VEGF (Fig. 1H) were significantly higher in mammary tumour colonies than in the corresponding healthy tissues (Fig. 1). 

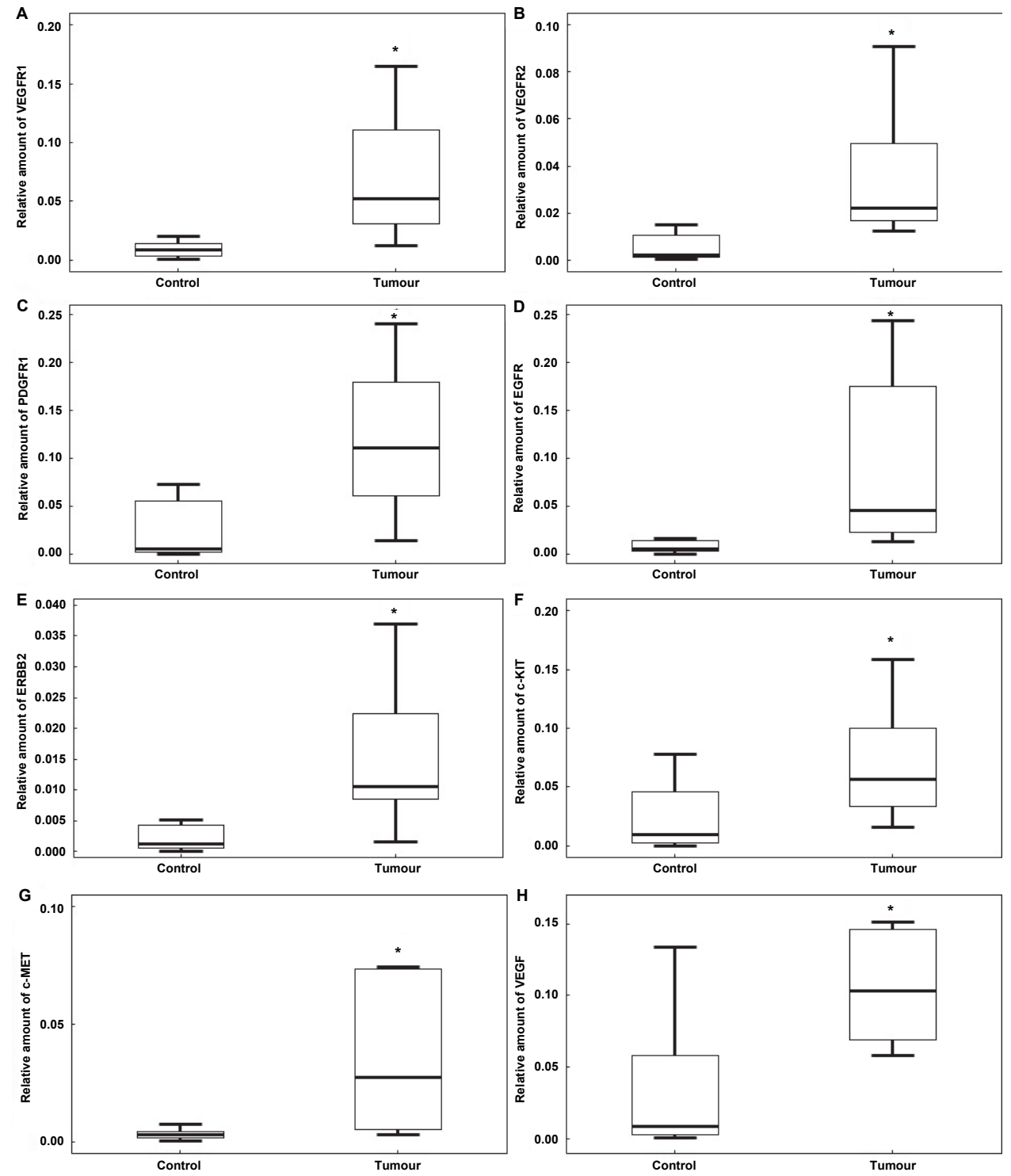

Fig. 1. Box plots of growth factor receptor and VEGF transcription levels in healthy tissue (control, $\mathrm{n}=13$ ) and canine mammary cancer samples (tumour, $\mathrm{n}=13$ ) taken from the same individual. (A) VEGFR1 expression, (B) VEGFR2 expression, (C) PDGFR1 expression, (D) EGFR expression, (E) ErbB2 expression, (F) c-KIT expression, (G) c-MET expression, (H) VEGF expression.

Student's $t$-test was applied. Significant differences at $\mathrm{P}<0.05$ are indicated by asterisk

To see if tumour grading was important in the expression of these proteins, VEGFR1, PDGFR1, VEGF, EGFR, c-KIT and c-MET expression values 
were compared using Kruskal-Wallis ANOVA method in Grade I $(\mathrm{n}=5)$, Grade II $(n=5)$ and Grade III $(n=3)$ mammary cancers compared to their controls (Fig. 2).


Fig. 2. Box plots of the relative expression of VEGF and growth factor receptors in healthy (control) and canine mammary tumour tissues of different grades: Grade I $(n=5)$, Grade II $(n=5)$ and Grade III ( $\mathrm{n}=3$ ). (A) VEGFR1 expression, (B) VEGFR2 expression, (C) PDGFR1 expression, (D) EGFR expression, (E) ErbB2 expression, (F) c-KIT expression, (G) c-MET expression, (H) VEGF expression. Kruskal-Wallis ANOVA was applied. Significant differences between tumour samples and their corresponding control groups at $\mathrm{P}<0.05$ are indicated by asterisk, and between different grade groups by Gr I, Gr II and Gr III 
VEGFR1 expression in Grade I tumours was not different from that measured in the corresponding control samples, but higher grade rating was associated with higher VEGFR1 expression. Significant differences were also found between Grade I and II $(\mathrm{P}=0.014)$, Grade I and III $(\mathrm{P}=0.023)$, as well as Grade II and III $(\mathrm{P}=0.016)$ samples (Fig. 2A).

An opposite tendency could be observed in VEGFR2 expression, where mRNA level was highest in Grade I tumours, lower in Grade II and even lower in Grade III (Fig. 2B). In all three cases, the mRNA levels were significantly higher in the tumour samples than in the controls: in Grade I $(\mathrm{P}=0.046)$, in Grade II $(\mathrm{P}=0.008)$ and in Grade III $(\mathrm{P}=0.015)$.

Similar tendencies were observed for PDGFR1 (Fig. 2C), EGFR (Fig. 2D) and ErbB2 (Fig. 2E). Higher expressions were measured in Grade I mammary cancer biopsies than in the corresponding controls or in Grade II as well as Grade III samples, even though not all the differences proved to be significant.

The expression of c-KIT (Fig. 2F), c-mMETt (Fig. 2G) and VEGF (Fig. $2 \mathrm{H}$ ) in tumours of different grades resembled that of VEGFR1. There was no difference between the mRNA levels of control and Grade I tumour samples, but with higher grading the expression increased significantly, and was highest in Grade II and/or Grade III cancers.

When pairwise comparisons were made using tumour samples with their corresponding individual controls (Fig. 3), significant differences could be observed only for VEGFR1, PDGFR1, c-KIT and c-MET. mRNA levels of VEGFR1 (Fig. 3A) in Grade III tumours were higher than in Grade I $(\mathrm{P}=0.005)$ and Grade II samples ( $\mathrm{P}=0.037)$. Levels of PDGFR1 (Fig. 3C) in Grade III samples were significantly decreased compared to Grade I $(\mathrm{P}=0.048)$ and Grade II $(\mathrm{P}=$ 0.045 ) tumours. While the expression of c-KIT (Fig. 3F) and c-MET (Fig. 3G) in Grade III samples showed a significant increase compared to Grade I $(\mathrm{P}=0.049$ and $\mathrm{P}=0.049$, respectively $)$ and Grade II $(\mathrm{P}=0.048$ and $\mathrm{P}=0.049$, respectively $)$ cancers.

\section{Discussion}

The overexpression of HER-2 in 20-30\% of human breast cancer cases has been known for a while. The increased presence of this protein has also been acknowledged in tumourigenesis: it causes shorter recurrence-free and overall survival time, as well as a worse prognosis in general (Slamon et al., 1989). Immunohistochemical studies performed on a large sample (91 malignant and 6 benign breast tumours, 2 healthy controls) have demonstrated increased expression of HER-2 in $29.7 \%$ of human malignancies. In contrast to human breast tumours, the overexpression of HER-2 in dogs with only surgical treatment has been associated with longer survival (Hsu et al., 2007). 

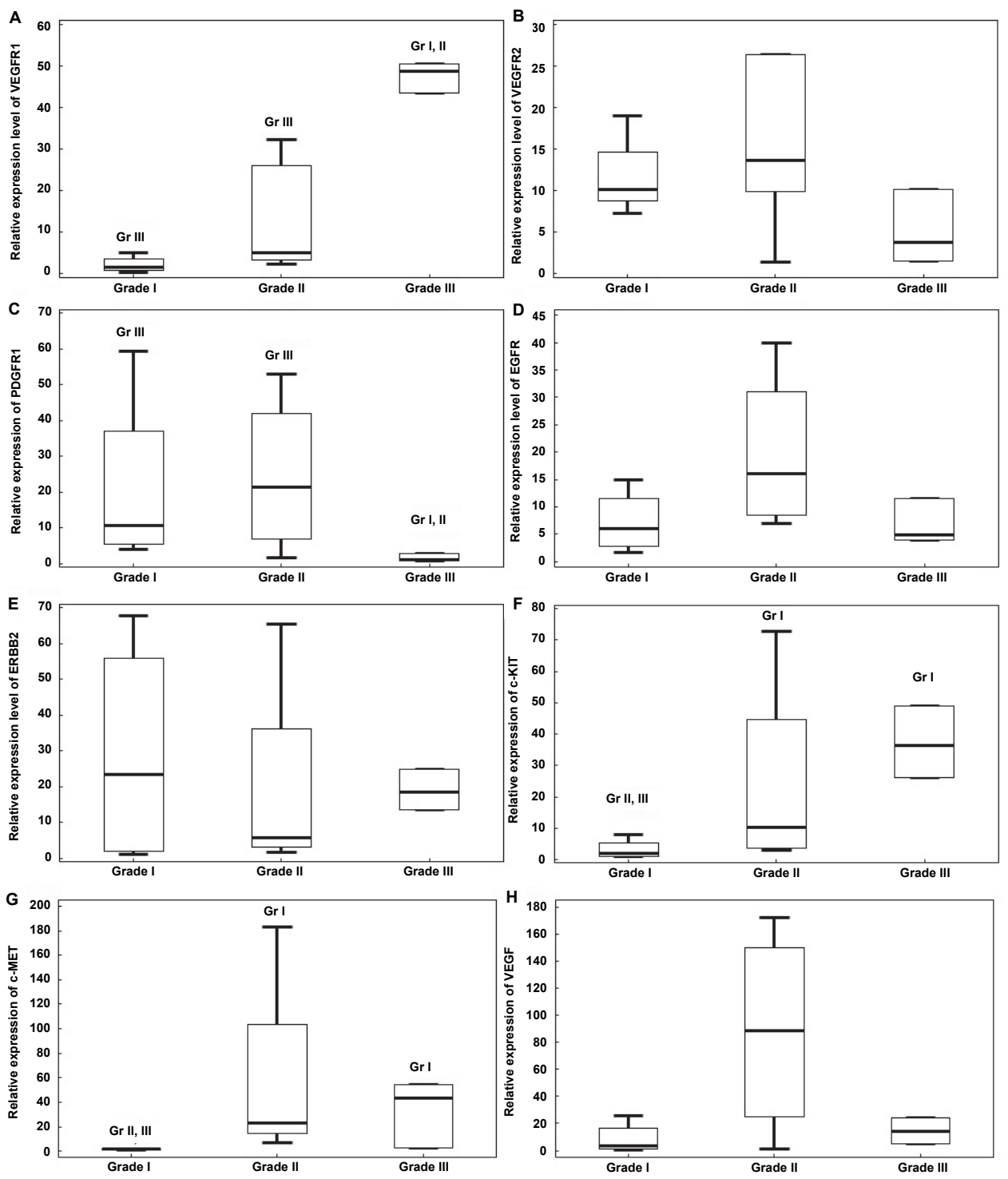

Fig. 3. Box plots of a pairwise comparison of the relative expression of VEGF and growth factor receptors in healthy (control) and canine mammary tumour tissues of different grades: Grade I $(\mathrm{n}=5)$, Grade II $(\mathrm{n}=5)$ and Grade III $(\mathrm{n}=3)$. (A) VEGFR1 expression, (B) VEGFR2 expression, (C) PDGFR1 expression, (D) EGFR expression, (E) ErbB2 expression, (F) c-KIT expression, (G) c-MET expression, (H) VEGF expression. Mann-Whitney test was used and significant differences between different grade groups at $\mathrm{P}<0.05$ are indicated by Gr I, Gr II and Gr III

Increased expression of VEGF and VEGF-1/-2 (Flt-1/KDR) in canine mammary tumours has also been described by several authors. They suggested 
the presence of an autocrine loop, but reported contradictory results with regard to prognosis, survival, malignancy, and tumour microvessel density (Restucci et al., 2004; Millanta et al., 2006; Al-Dissi et al., 2010).

Masitinib and toceranib are tyrosine kinase inhibitors. Their use is approved in mast cell tumours of dogs by the U.S. Food and Drug Administration and are commercially available under the name Masivet ${ }^{\circledR} /$ Kinavet $^{\circledR}$ and Palladia ${ }^{\circledR}$, respectively. Imatinib marketed as Gleevec ${ }^{\circledR}$ or Glivec ${ }^{\circledR}$ is another tyrosine kinase inhibitor used in the treatment of multiple cancers, most notably human chronic myelogenous leukaemia (Goldman and Melo, 2003) and GIST (De Giorgio and Verweij, 2005), but has been successfully used in dogs and cats as well (London et al., 2009). All three compounds target selected kinases, including KIT and PDGFR, but masitinib also acts on FGFR3 and Lyn tyrosine kinases (Hahn et al., 2008; Dubreuil et al., 2009). Toceranib is an inhibitor of VEGFR2 (London et al., 2009), while imatinib also inhibits BCR-Abl.

The objective of our study was to measure the mRNA levels of several proteins related to RTK signalling pathways which can be relevant in canine mammary cancers. The relative expression of tyrosine kinases like VEGFR1, VEGFR2, EGFR, ErbB2 (HER-2), PDGFR1/PDGFR $\alpha$, c-KIT and c-MET, as well as that of VEGF was measured using a quantitative real-time RT-PCR procedure. The results show that mRNA of all the above-listed proteins are present at higher levels in mammary cancer tissues than in healthy ones taken from the same animals. Regarding the increased expression of VEGFR1, VEGFR2 and VEGF, our results are in accordance with those published in several other studies on their elevated expression in canine mammary tumours and probably on the existence of an autocrine loop. Tumour cells are capable of producing VEGF, which attaches to the receptors triggering their autophosphorylation that leads to increased angiogenesis (Restucci et al., 2004; Millanta et al., 2006; Al-Dissi et al., 2010). VEGF, as an angiogenic factor, regulates endothelial cell differentiation, proliferation and migration via various routes, and has antiapoptotic properties.

Like us, Restucci et al. (2004) also found that the less differentiated (higher graded) tumours had significantly higher levels of VEGF and VEGFR1 than the less malignant ones. This might be due to the fact that higher graded tumours are more aggressive, therefore their growth is faster, developing hypoxic and necrotic areas. The study of Restucci et al. (2004) investigated VEGFR1 and VEGF expressions in breast tumours by immunohistochemistry and found that a highly increased expression was associated with a significant necrosis. It is likely that the VEGF-VEGFR autocrine loop is the response of the tumour to hypoxic stimulation. It can be assumed that in malignant tumours the VEGF-VEGFR axis has a key role in endothelial migration and proliferation and, simultaneously, in neoplastic cell proliferation and tumour growth. Moreover, increased VEGFR and VEGF expression can enhance metastatic tendency partly via neovascularisation, and partly by the increased permeability of the newly formed blood vessel 
walls. Overall, the above-cited authors also experienced increased expression of VEGF and VEGFR as a negative prognostic factor, which may explain some typical properties of high-grade breast tumours, including rapid growth and rapid metastasis.

Interestingly, significantly increased expression of VEGF and VEGFR1 was a consistent finding in high-grade (III) tumours analysed by two different methods, while the expression of EGFR2 did not show similar changes. Increased VEGFR2 levels were described in Grade III canine brain tumours (Dickinson et al., 2006), but the pattern of expression seemed to differ depending on the tumour type. This may indicate that VEGFR2 does not play a major role in canine mammary tumour progression and the signalling may occur predominantly through VEGFR1 receptor.

Increased expression of PDGFR1, EGFR and ErbB2 has been reported for human breast carcinomas. PDGFR1/PDGFR- $\alpha$ expression has been found to be highly expressed in human breast carcinomas and is associated with tumour progression (Carvalho et al., 2005). EGFR and ErbB2 overexpression is also observed in many subtypes of breast cancer (Bhargava et al., 2005; Tan and Yu, 2007; Masuda et al., 2012) and is associated with large tumour size, poor differentiation, and poor clinical outcomes.

In agreement with these findings, in our study increased levels of canine PDGFR1, EGFR and ErbB2 mRNA were seen, mainly in low-grade (I and II) mammary cancers. These receptors have been associated with the biological aggressiveness of tumours and, therefore, can be potential therapeutic targets in canine mammary tumours as well.

The c-KIT and c-MET pathways are associated with breast cancer progression in humans (Ho-Yen et al., 2015; Liu et al., 2015) and suggest that there is a firm basis for continued development of anti-c-KIT and anti-c-MET treatments. Increased c-KIT expression was also found in canine mammary tumours earlier by Kubo et al. (1998). Our results correlate with these findings, especially in Grade II and Grade III tumours.

Oncogenic RTKs play an important role in tumour proliferation, growth, angiogenesis and the formation of metastases (Stellrecht and Gandhi, 2009). Based on the presented data, we can confirm that increased expression of several RTKs is a common finding in canine mammary tumours of different grades, which may partly explain the aggressiveness of these tumours leading to a worse prognosis. Our results show, for the first time, a complex and simultaneous dysregulation of not only one receptor, but of several genes in these tumours, suggesting that RTK levels should be taken into consideration when planning an effective therapy.

The small sample size and sampling from different types of mammary tumours limit the conclusions that can be drawn from our results. However, the data presented provide evidence for the existence of overexpression and dysregula- 
tion of VEGF and several oncogenic tyrosine kinases in canine mammary tumours, particularly of VEGR1, PDGFR1, c-KIT and c-MET. In spite of the small number of patients, it should be considered that healthy and tumour samples were taken from the same animal at the same time, making statistical comparisons more reliable. In summary, canine mammary cancers may be candidates for trials of RTK-targeted antibodies or small tyrosine kinase inhibitory molecules.

\section{Acknowledgement}

The publication of this research was supported by the 17896-4/2018/ FEKUTSTRAT grant of the Hungarian Ministry of Human Resources.

\section{References}

Al-Dissi, A. N., Haines, D. M., Singh, B. and Kidney, B. A. (2010): Immunohistochemical expression of vascular endothelial growth factor and vascular endothelial growth factor receptor2 in canine simple mammary gland adenocarcinomas. Can. Vet. J. 51, 1109-1114.

Bergman, P. J. (2000): Multidrug resistance. In: Kirk, R. W. (ed.) Current Veterinary Therapy XIII. W. B. Saunders Co., Philadelphia. pp. 479-482.

Bhargava, R., Gerald, W. L., Li, A. R., Pan, Q., Lal, P., Ladanyi, M. and Chen, B. (2005): EGFR gene amplification in breast cancer: correlation with epidermal growth factor receptor mRNA and protein expression and HER-2 status and absence of EGFR-activating mutations. Mod. Pathol. 18, 1027-1033.

Carvalho, I., Milanezi, F., Martins, A., Reis, R. M. and Schmitt, F. (2005): Overexpression of platelet-derived growth factor receptor $\alpha$ in breast cancer is associated with tumour progression. Breast Cancer Res. 7, R788. DOI: 10.1186/bcr1304.

Cassali, G. D., Lavalle, G. E., De Nardi, A. B., Ferreira, E., Bertagnolli, A. C., Estrela-Lima, A. et al. (2011): Consensus for the diagnosis, prognosis and treatment of canine mammary tumors. Braz. J. Vet. Pathol. 4, 153-180.

Cherrington, J. M., Strawn, L. M. and Shawver, L. K. (2008): New paradigms for the treatment of cancer: the role of anti-angiogenesis agents. Adv. Cancer Res. 79, 1-38.

Clemente, M., Sánchez-Archidona, A. R., Sardón, D., Díez, L., Martín-Ruiz, A., Caceres, S., Sassi, F., Dolores Pérez-Alenza, M., Illera, J. C., Dunner, S. and Peña, L. (2013): Different role of COX-2 and angiogenesis in canine inflammatory and non-inflammatory mammary cancer. Vet. J. 197, 427-432.

De Giorgio, U. and Verweij, J. (2005): Imatinib and gastrointestinal stromal tumors: Where do we go from here? Mol. Cancer Ther. 4, 495-501.

Dickinson, P. J., Roberts, B. N., Higgins, R. J., Leutenegger, C. M., Bollen, A. W., Kass, P. H. and LeCouteur, R. A. (2006): Expression of receptor tyrosine kinases VEGFR-1 (FLT-1), VEGFR-2 (KDR), EGFR-1, PDGFRalpha and c-Met in canine primary brain tumours. Vet. Comp. Onc. 4, 132-140.

Downing, S., Chien, M. B., Kass, P. H., Moore, P. E. and London, C. A. (2002): Prevalence and importance of internal tandem duplications in exons 11 and 12 of c-kit in mast cell tumors of dogs. Am. J. Vet. Res. 63, 1718-1723. 
Dubreuil, P., Letard, S., Ciufolini, M., Gros, L., Humbert, M., Castéran, N., Borge, L., Hajem, B., Lermet, A., Sippl, W., Voisset, E., Arock, M., Auclair, C., Leventhal, P. S., Mansfield, C. D., Moussy, A. and Hermine, O. (2009): Masitinib (AB1010), a potent and selective tyrosine kinase inhibitor targeting KIT. PLoS One 4, e7258.

Frost, D., Lasota, J. and Miettinen, M. (2003): Gastrointestinal stromal tumors and leiomyomas in the dog: a histopathologic, immunohistochemical, and molecular genetic study of 50 cases. Vet. Pathol. 40, 42-54.

Galli, S. J., Zsebo, K. M. and Geissler, E. N. (1994): The kit ligand, stem cell factor. Adv. Immunol. 55, 1-95.

Goldman, J. M. and Melo, J. V. (2003): Chronic myeloid leukemia - advances in biology and new approaches to treatment. N. Engl. J. Med. 349, 1451-1464.

Hahn, K. A., Ogilvie, G., Rusk, T., Devauchelle, P., Leblanc, A., Legendre, A., Powers, B., Leventhal, P. S., Kinet, J. P., Palmerini, F., Dubreuil, P., Moussy, A. and Hermine, O. (2008): Masitinib is safe and effective for the treatment of canine mast cell tumors. J. Vet. Int. Med. 22, 1301-1309.

Ho-Yen, C. M., Jones, J. L. and Kermorgant, S. (2015): The clinical and functional significance of c-Met in breast cancer: a review. Breast Cancer Res. 17, 52.

Hsu, W. L., Huang, H. M., Liao, J. W., Wong, M. L. and Chang, S. C. (2007): Increased survival in dogs with malignant mammary tumours overexpressing HER-2 protein and detection of a silent single nucleotide polymorphism in the canine HER-2 gene. Vet. J. 180, 116-123.

Kubo, K., Matsuyama, S., Katayama, K., Tsutsumi, C., Yonezawa, K., Shimada, T., Kotani, T., Sakuma, S., Ohashi, F. and Takamori, Y. (1998): Frequent expression of the c-kit protooncogene in canine malignant mammary tumor. J. Vet. Med. Sci. 60, 1335-1340.

Lemmon, M. A. and Schlessinger, J. (2010): Cell signaling by receptor tyrosine kinases. Cell 141, $1117-1134$.

Liu, J., Liu, X., Feng, X., Liu, J., Lv, S., Zhang, W. and Niu, Y. (2015): C-kit overexpression correlates with KIT gene copy numbers increases in phyllodes tumors of the breast. Breast Cancer Res. Treat. 149, 395-401.

London, C. A. (2013): Molecular/targeted therapy of cancer, Section B. Signal transduction and cancer. In: Withrow, S., Vail, D. and Page, R. (eds) Withrow and MacEwen's Small Animal Clinical Oncology, 5th edition. W. B. Saunders Co., Philadelphia. pp. 221-229.

London, C. A., Malpas, P. B., Wood-Follis, S. L., Boucher, J. F., Rusk, A. W., Rosenberg, M. P., Henry, C. J., Mitchener, K. L., Klein, M. K., Hintermeister, J. G., Bergman, P. J., Couto, G. C., Mauldin, G. N. and Michels, G. M. (2009): Multi-center, placebo-controlled, double-blind, randomized study of oral toceranib phosphate (SU11654), a receptor tyrosine kinase inhibitor, for the treatment of dogs with recurrent (either local or distant) mast cell tumor following surgical excision. Clin. Cancer Res. 15, 3856-3865.

Masuda, H., Zhang, D., Bartholomeusz, C., Doihara, H., Hortobagyi, G. N. and Ueno, N. T. (2012): Role of epidermal growth factor receptor in breast cancer. Breast Cancer Res. Treat. 136, 10.1007/s10549-012-2289-9.

Merlo, D. F., Rossi, L., Pellegrino, C., Ceppi, M., Cardellino, U., Capurro, C., Ratto, A., Sambucco, P. L., Sestito, V., Tanara, G. and Bocchini, V. (2008): Cancer incidence in pet dogs: Findings of the animal tumor registry of Genoa, Italy. J. Vet. Int. Med. 22, 976-984.

Millanta, F., Silvestri, G., Vaselli, C., Citi, S., Pisani, G., Lorenzi, D. and Poli, A. (2006): The role of vascular endothelial growth factor and its receptor Flk-1/KDR in promoting tumour angiogenesis in feline and canine mammary carcinomas: a preliminary study of autocrine and paracrine loops. Res. Vet. Sci. 81, 350-357.

Patruno, R., Marech, I., Zizzo, N., Ammendola, M., Nardulli, P., Gadaleta, C., Introna, M., Capriuolo, G., Rubini, R. A., Ribatti, D., Gadaleta, C. D. and Ranieri, G. (2014): C-Kit expression, angiogenesis, and grading in canine mast cell tumour: A unique model to study c-Kit driven human malignancies. Biomed. Res. Intern. 12, 2014:730246. Epub 2014 May 12. 
Restucci, B., Borzacchiello, G., Maiolino, P., Martano, M., Paciello, O. and Papparella, S. (2004): Expression of vascular endothelial growth factor receptor Flk-1 in canine mammary tumours. J. Comp. Pathol. 130, 99-104.

Slamon, D. J., Godolphin, W., Jones, L. A., Holt, J. A., Wong, S. G., Keith, D. E., Levin, W. J., Stuart, S. G., Udove, J., Ullrich, A. and Press, F. (1989): Studies of the HER-2/neu protooncogene in human breast and ovarian cancer. Science 244, 707-712.

Stellrecht, C. M. and Gandhi, V. (2009): MET receptor tyrosine kinase as a therapeutic anticancer target. Cancer Lett. 280, 1-14.

Stommel, J. M., Kimmelman, A. C., Ying, H., Nabioullin, R., Ponugoti, A. H., Wiedemeyer, R., Stegh, A. H., Bradner, J. E., Ligon, K. L., Brennan, C., Chin, L. and DePinho, R. A. (2007): Coactivation of receptor tyrosine kinases affects the response of tumor cells to targeted therapies. Science 318, 287-290.

Tan, M. and Yu, D. (2007): Molecular mechanisms of ErbB2-mediated breast cancer chemoresistance. Adv. Exp. Med. Biol. 608, 119-129.

$\mathrm{Xu}$, A. M. and Huang, P. H. (2010): Receptor tyrosine kinase coactivation networks in cancer. Cancer Res. 10, 3857-3860. 